\title{
Antibody Responses In Bangladeshi Children Following Measles Vaccination.
}

\author{
Sharmin Sultana ${ }^{1}$ Shahina Tabassum ${ }^{1}$ Afzalun Nessa ${ }^{1}$ Munira Jahan ${ }^{1}$ \\ ${ }^{1}$ Department of Virology, Bangabandhu Sheikh Mujib Medical University, Dhaka.
}

Submitted on: 13 March, 2015. Accepted on: 20 June, 2015

\begin{abstract}
:
Measles is a highly contagious vaccine preventable viral disease which mainly affects children. Infection with wild measles virus induces an immune response that provides life long protection. Measles has been targeted for global eradication. In Bangladesh, there is insufficient data about the antibody responses in children following measles vaccination. In the present study, the antibody response of a single dose of measles vaccine was investigated among 77 children of different age groups. The humoral immune response immunoglobin $\operatorname{IgG}$ (IgG) was detected by a commercial Enzyme-linked Immunosorbent Assay (ELISA). Among the study population, detectable antibody titer was observed in $75.3 \%$ children while $24.7 \%$ showed detectable titers. The mean antibody concentration was highest $(2.75 \pm 1.10 \mathrm{IU} / \mathrm{ml})$ in the $13-24$ months age group, decreased gradually with age, and was lowest $(0.77 \pm 0.13 \mathrm{IU} / \mathrm{ml}) \mathrm{in}$ the 85 96 months age group. Thereafter, the mean antibody concentration gradually increased again in the $97-108 \mathrm{months}(1.20 \pm 0.13 \mathrm{IU} / \mathrm{ml})$ and in the 109-120 months $(1.45 \pm 0.13 \mathrm{IU} / \mathrm{ml})$ age groups. The mean antibody titer was statistically significant in relation to age $(\mathrm{p}<0.01)$ but not to gender $(\mathrm{p}<0.95)$. This study showed that around $25 \%$ children remained antibody negative indicating challenges ahead for eradication of measles from Bangladesh.
\end{abstract}

Keyword: Bangladesh, Children, Measles IgG, Measles vaccination.

\section{Introduction:}

Measles is a ubiquitous, highly infectious disease. In the absence of proper immunization programmes, it affects nearly every person in a given population by adolescence (Black, 1982). ${ }^{1}$ The introduction of an effective live attenuated virus vaccine has dramatically reduced the incidence of measles. However, measles has not been eliminated because of failure to vaccinate all children before they reach school age and due to cases of vaccine failure. Vaccine effectiveness is expected to be at least $85 \%$ when measles vaccine is administered at nine months of age but cold chain and other program failures have reduced the effectiveness in both rural and urban areas in developing countries. ${ }^{2}$ Worldwide, more than 20 million people are affected by measles annually. In 2006, there were approximately 2,42,000 measles deaths globally, which amounts to 663 deaths every day or 27 deaths every hour. ${ }^{3}$ The majority (>95\%) of measles deaths occur in countries with poor resources and weak health infrastructure. ${ }^{4}$ Children usually do not die directly from measles, but from its complications. The commonest complications of measles are

\section{$\triangle 0$ Correspondence:}

Dr. Sharmin Sultana

Medical officer Dept. of Virology,

Bangabandhu Sheikh Mujib Medical University

Telephone No: 01711892431

E-mail address: sharmins34@yahoo.com otitis media ( $7 \%$ to $9 \%$ ), pneumonia ( $1 \%$ to $6 \%$ ), post infection encephalitis (1/1000 to $1 / 2000$ cases), sub acute sclerosing pan encephalitis (SSPE) (1/100000 cases) with mortality rate of $1 / 10000$ cases. Complications are more common in children under the age of five years. ${ }^{5}$ In countries where measles has been eliminated, cases imported from other countries remain an important source of infection. ${ }^{2}$ In South East Asian region, the estimated number of deaths due to measles was $1,36,000$ in 2007 (69\% of global measles mortality). In India, the number of measles cases was 48,181 in 2008. In 2005, the number of measles cases was about 25,935 in Bangladesh, which decreased to approximately 2,660 cases in 2008 after Measles Catch-up Campaign. The campaign targeted 35 million children aged between 9 months and less than 10 years, irrespective of their previous vaccination status or illness. ${ }^{6}$ The World Health Organization (WHO) and the United Nations Initiative for Children Fund (UNICEF) have identified 47 priority countries as targets for implementation of accelerated sustainable measles mortality reduction activities and Bangladesh is included among these countries. ${ }^{4}$ Recent progress in reducing global measles mortality arise the interest in measles eradication. During 2000-2008, a second opportunity for measles immunization was provided in $46 / 47$ priority countries (with the exception of India), leading to vaccination of approximately 686 million children aged 9 months to 14 years through Supplementary 
Immunization Activities (SIAs). ${ }^{6}$ In Bangladesh, the measles vaccine coverage reached $93 \%$ in $2009 .{ }^{7}$ Measles vaccine induces both humoral immunity and cell mediated immune (CMI) responses. The response to vaccination is similar to that caused by natural infection with an initial transient rise in serum $\operatorname{IgM}$ and a later rise in IgG. Persons who have experienced an initial antigenic stimulation from either natural measles or vaccines generally exhibit an anamnestic or secondary response after either vaccination or exposure to natural measles. ${ }^{8}$ This secondary response is characterized by rapid and often transient increase in IgG antibody. ${ }^{9}$ Though measles has been targeted for global eradication but currently, there is insufficient data from Bangladesh regarding the antibody responses in children following measles vaccination. The present study was thus designed to determine the measles IgG antibody level among vaccinated Bangladeshi children aged from 1-10 years.

\section{Materials and Methods:}

Study population: This cross sectional study was carried out at the Department of Virology, Bangabandhu Sheikh Mujib Medical University (BSMMU) among children who were previously vaccinated with measles vaccine at the end of nine months of age in January 2009-December 2009. Children who had Expanded Programme on immunization (EPI) vaccination cards and whose parents gave written consent to collect blood samples were included in this study. Children who received blood product or immunoglobulin as passive immunization within last 6 months and whose parents did not give written consent were excluded from this study.

Blood samples were collected from the Laboratory Services Center of BSMMU and all laboratory works were performed at the Department of Virology, BSMMU. All relevant information and vaccination history were recorded in a standard pre-designed data sheet by interviewing the guardians of the children from whom blood was taken. Informed parental consent was taken before collection of blood samples. A total of 77 healthy children (39 males and 38 females) were selected. These children were divided according to age groups from 13-24 months, 25-36 months, 37-48 months, 49-60 months, 61-72 months, 73-84 months, 85-96 months, 97-108 months and 109-120 months into nine groups with 12 months interval. The study children were again divided into 2 groups: i.e pre-school (13-60 months) and school going (61-120 months).

Detection of Measles IgG: Approximately $3 \mathrm{ml}$ venous blood was collected by venipuncture technique and kept for half an hour in room temperature. To separate serum blood samples were centrifuged at $3000 \mathrm{rpm}$ for 5 minutes to separate serum.
The separated sera were stored at $-20^{\circ} \mathrm{C}$ until further use. All samples were tested for measles IgG by the commercial anti measles virus Immunoglobulin $\mathrm{G}$ assay ELISA test kit (Human Laboratory, Germany) according to the manufacturer's instructions.

Statistical analysis: Data were analyzed using SPSS 15 version software (USA). ANOVA and Chi-squire tests were done where applicable. Results were considered significant when the p-value was less than 0.05 .

\section{Results:}

The present study was carried out among 77 children who were vaccinated with measles vaccine. The age range of the study population was 1 to 10 years (with mean age 54 months \pm 3 months). Among the children, $75.3 \%$ had detectable antibody titer, while $24.7 \%$ had undetectable antibody titer after measles vaccination. Antibody titer $\geq 0.53 \mathrm{IU} / \mathrm{ml}$ was considered as detectable while antibody titer $<0.53 \mathrm{IU} / \mathrm{ml}$ was considered as undetectable. Among the children, the age specific mean antibody concentration was highest $(2.75 \pm$ $1.10 \mathrm{IU} / \mathrm{ml})$ in the $13-24$ months age group while it was lowest $(0.77 \pm 0.35 \mathrm{IU} / \mathrm{ml})$ in $85-96$ months age group. It was also observed that the titer gradually increased to $(1.20 \pm 0.13$ $\mathrm{IU} / \mathrm{ml})$ in $97-108$ months and further increase to $(1.45 \pm 0.15$ $\mathrm{IU} / \mathrm{ml}$ ) in 109-120 months age group and this increase was statistically significant $(\mathrm{p}<0.01)$. The detectable antibody titer was highest (90\%) in 25-36 months age group and lowest (62.5\%) in 73-84 months age group (Table-1). Among all the studied children, 40 children $(51.94 \%)$ were below 5 years of age, and 37 (48.05\%) were above 5 years of age (Table-2). It was observed that in children below 5 years of age, 31 $(77.50 \%)$ had detectable antibody titer $(2.08 \pm 1.3 \mathrm{IU} / \mathrm{ml})$. Moreover, it was also observed that in children above 5 years of age, $27(72.97 \%)$ had detectable titer $(1.07 \pm 0.60 \mathrm{IU} / \mathrm{ml})$. The difference between mean antibody titer in these two age groups were statistically significant $(\mathrm{p}<0.01)$ indicating that the falling titer of measles $\operatorname{IgG}$ in school going children.

Among all the children after study, 39 (50.6\%) were male while 38 (49.4\%) were female children. Among male children, $33(84.6 \%)$ children had detectable titer $(1.71 \pm 1.34$ IU/ml) while among female children, 25 (65.8\%) had detectable titer $(1.78 \pm 1.14 \mathrm{IU} / \mathrm{ml})$. However, the difference between mean antibody titer among male and female children was not statistically significant $(\mathrm{p}<0.95)$ but the antibody response between male and female children was significant $(\mathrm{p}<0.01)($ Table-2). 
Table-1: Anti-measles IgG responses after measles vaccination according to age groups.

\begin{tabular}{|c|c|c|}
\hline \multirow[b]{2}{*}{$\begin{array}{l}\text { Age group } \\
\text { (in months) }\end{array}$} & \multicolumn{2}{|c|}{ Measles antibody (IgG) titer in IU/ml * } \\
\hline & $\begin{array}{c}\text { Antibody Positive } \\
\text { n (\%) } \\
\text { Titer (Mean } \pm \text { SD) }\end{array}$ & $\begin{array}{c}\text { Antibody Negative } \\
\text { n(\%) } \\
\text { Titer (Mean } \pm \text { SD) }\end{array}$ \\
\hline $13-24$ & $\begin{array}{c}8(80 \%) \\
(2.75 \pm 1.10)\end{array}$ & $\begin{array}{c}2(20 \%) \\
(0.32 \pm 0.06)\end{array}$ \\
\hline $25-36$ & $\begin{array}{c}9(90 \%) \\
(2.52 \pm 1.09)\end{array}$ & $\begin{array}{c}1(10 \%) \\
0.31\end{array}$ \\
\hline $37-48$ & $\begin{array}{c}7(70 \%) \\
(1.95 \pm 0.61)\end{array}$ & $\begin{array}{c}3(30 \%) \\
(0.30 \pm 0.07)\end{array}$ \\
\hline $49-60$ & $\begin{array}{c}7(70 \%) \\
(1.28 \pm 0.31)\end{array}$ & $\begin{array}{c}3(30 \%) \\
(0.32 \pm 0.08)\end{array}$ \\
\hline $61-72$ & $\begin{array}{c}6(66.7 \%) \\
(1.05 \pm 0.35)\end{array}$ & $\begin{array}{c}3(33.3 \%) \\
(0.30 \pm 0.06)\end{array}$ \\
\hline $73-84$ & $\begin{array}{c}5(62.5 \%) \\
(0.91 \pm 0.16)\end{array}$ & $\begin{array}{c}3(37.5 \%) \\
(0.31 \pm 0.05)\end{array}$ \\
\hline $85-96$ & $\begin{array}{c}6(75 \%) \\
(0.77 \pm 0.35)\end{array}$ & $\begin{array}{c}2(25 \%) \\
(0.30 \pm 0.04)\end{array}$ \\
\hline $97-108$ & $\begin{array}{c}6(85.7 \%) \\
(1.20 \pm 0.13)\end{array}$ & $\begin{array}{c}1(14.2 \%) \\
0.32\end{array}$ \\
\hline $109-120$ & $\begin{array}{c}4(80 \%) \\
(1.45 \pm 0.15)\end{array}$ & $\begin{array}{c}1(20 \%) \\
0.33\end{array}$ \\
\hline Total & $58(75.3 \%)$ & $19(24.7 \%)$ \\
\hline
\end{tabular}

ANOVA test was done.

*According to ELISA kit used in this study,

Antibody titer $\geq 0.53 \mathrm{IU} / \mathrm{ml}$ was considered as positive.

Antibody titer $<0.53 \mathrm{IU} / \mathrm{ml}$ was considered as negative.

Table-2: Anti-measles IgG response after measles vaccination in pre school and school going children.

\begin{tabular}{|c|c|c|c|c|}
\hline & \multirow{2}{*}{$\begin{array}{l}\text { Number of } \\
\text { children } \\
\text { n (\%) }\end{array}$} & \multicolumn{2}{|c|}{ Measles antibody (IgG) titer in IU/ml * } & \multirow[t]{2}{*}{ P value } \\
\hline & & $\begin{array}{c}\text { Antibody Positive } \\
\text { n (\%) } \\
\text { Titer (Mean } \pm \text { SD) }\end{array}$ & $\begin{array}{c}\text { Antibody Negative } \\
\text { n(\%) } \\
\text { Titer }(\text { Mean } \pm \text { SD) }\end{array}$ & \\
\hline \multicolumn{5}{|l|}{$\begin{array}{l}\text { Age in } \\
\text { Months }\end{array}$} \\
\hline $13-60$ & $40(51.9)$ & $\begin{array}{c}31(77.5) \\
(2.08 \pm 1.3)\end{array}$ & $\begin{array}{c}9(22.5) \\
(0.31 \pm 0.06)\end{array}$ & $<0.001$ \\
\hline $61-120$ & $37(48.1)$ & $\begin{array}{c}27(72.9) \\
(1.07 \pm 0.60)\end{array}$ & $\begin{array}{c}10(27.1) \\
(0.32 \pm 0.05)\end{array}$ & \\
\hline \multicolumn{5}{|l|}{ Gender } \\
\hline Male & $39(50.6 \%)$ & $\begin{array}{l}33(84.6 \%) \\
(1.71 \pm 1.34)\end{array}$ & $\begin{array}{c}6(15.4 \%) \\
(0.33 \pm 0.07)\end{array}$ & $<0.001$ \\
\hline Female & $38(49.4 \%)$ & $\begin{array}{c}25(65.8 \%) \\
(1.78 \pm 1.14)\end{array}$ & $\begin{array}{c}13(34.2 \%) \\
(0.30 \pm 0.01)\end{array}$ & $<0.955$ \\
\hline
\end{tabular}

Chi-square test was done

*According to ELISA kit used in this study,

Antibody titer $\geq 0.53 \mathrm{IU} / \mathrm{ml}$ was considered as positive.

Antibody titer $<0.53 \mathrm{IU} / \mathrm{ml}$ was considered as negative.

\section{Discussion:}

Worldwide, measles is the fifth leading cause of mortality among children less than 5 years of age. ${ }^{10}$ Fortunately, measles is a vaccine preventable disease; infection with wild measles virus induces an immune response that provides life long protection. ${ }^{11}$ However, despite the availability of a safe and effective vaccine measles has yet not been eliminated. Several studies have observed that antibody levels following vaccination is lower than those following natural infection. ${ }^{12,13,14}$ Other investigators have found evidence of waning immunity among vaccinated children. ${ }^{15,16}$ Since the introduction of live attenuated measles vaccines, a gradual decline in the level of measles antibodies over time after immunization has been $11,17-20$ Moreover, it has been established that children with high antibody level seems to be completely protected against clinical disease whereas children with sufficiently low antibody levels are at risk of mild or subclinical measles infections. ${ }^{13,21,22}$ In our study, it was observed that $75.3 \%$ of the study children had detectable antibody titer while $24.7 \%$ did not have detectable titer after vaccination. A previous study carried out at the Department of Virology, BSMMU, among vaccinated children found detectable measles antibodies in $62 \%$ children while $38 \%$ did not show detectable antibodies.23 A number of factors may be considered as the cause of vaccine failure, such as, interference of vaccine antigen by maternal antibody in early age, improper storage and transport of vaccine or its administration. ${ }^{9}$ In a study from Brazil, only $44 \%$ of children aged 9-15 years were antibody positive while a study from Poland observed that measles antibody was below the protective level in $22.5 \%$ of children. ${ }^{24}$ In our study, measles antibody was detected in $80 \%$ children in the $13-24$ months age group and $90 \%$ children in the $25-36$ months age group, which gradually decreased to $62.5 \%$ in the $37-84$ months age group. However, from the 85-96 months age group it increased again to $75 \%$ reaching $86 \%$ in the $97-108$ months and $80 \%$ in $109-120$ age groups. In our study, the mean antibody concentration was highest in the 13-24 months age group, but it was lowest in 85-96 months age groups. Our study also observed that $77.5 \%$ children below 5 years of age had detectable antibody titer while it was $72.9 \%$ in children above 5 years of age. Various prospective serological studies have reported a gradual decline in measles antibody titer during several years after vaccination. ${ }^{15,16,25,26}$ A study from Egypt reported a trend of decreasing mean antibody titers with increasing age among children below the age of 8 years with a significant increase in antibody titer in older age group of 10 to 12 years ${ }^{27}$ which was similar to present study. After a certain period of vaccination, elevation of antibody titer is most likely due to boosting effect from repeated exposure to circulating wild virus resulting in inapparent infection. However, the gradual decline of antibody response with time may be due to that antibodies may have responded adequately 
to the initial vaccination and experienced a subsequent decline in antibody titer over time (a secondary vaccine failure). The accepted measles vaccine failure rate is $>10 \% .^{28}$ Thus, WHO recommends that countries where risk of infant infection with measles virus is high, administration of first dose of measles vaccine (MCV1) should be at 9 months of age and second dose of measles vaccine (MCV2) at 15-18 months. Moreover, countries with less risk of measles infection administration of should be MCV1 at 12 months and MCV2 at 15-18 months or school-entry, depending on which age enables achievement of the highest routine MCV2 vaccination coverage. However, Bangladesh introduced a second dose of measles vaccine for children at the age of 15 months in 2012 with an aim to ensure early protection of the individual, slowing down accumulation of susceptible young children and may correspond to other routine immunizations (for example, a DTP booster).

In this present study, there was no relationship between gender and mean antibody concentration though the mean antibody concentration was slightly higher in female than in male children, but this was not statistically significant. Similar findings were reported by other researchers. ${ }^{26-27,}{ }^{29}$ However in the present study significantly higher number of male children had detectable antibody titer than the female children and the reason of these findings are unexplained. In some studies significant difference between boys and girls were reported. ${ }^{29}$

\section{Conclusion:}

The present study showed that around $25 \%$ children remained antibody negative for measles even after $93 \%$ coverage of measles vaccination indicating huge challenges ahead for measles eradication from Bangladesh.

\section{References:}

1. Black, F. L. The role of herd immunity in control of measles. Yale J Biol Med: 1982; 55:352-360.

2. Syed MA, Cutts FT, Hossain MJ, Wahedi OK, Nahar N, Islam D, Shaha NCM. Measles vaccine effectiveness and risk factor for measles in Dhaka, Bangladesh. Bull WHO 2002; 80:1-10.

3. World Health Organization, Geneva. WHO /Measles. Retrieved October 10, 2008 from http://www.who.int/media centre/factsheets/fs286/en/.

4. James K. Predicting and comparing long-term measles antibody profiles of different immunization policies. Bull WHO 2001; 79: 615-624.

5. Preblud, S. R., Mitchell, C. D., \& Scott G. B. (1988). Fatal measles pneumonia without rash in a child with AIDS. J Infec Dis 158: 480-483.

6. World Health Organization, Geneva. EPI Fact Sheet, Bangladesh, 2009. Available from: URL:
http://www.searo.who.int/en/Section1226/Section1635/ Section 1657.htm.

7. National Coverage Evaluation Survey Report (NCES), 20011. DGHS, Mohakhali, Dhaka-1212.

8. Linnenmann CC, Hegg ME. Measles IgM response during reinfection of previously vaccinated children. J Pediatr 1973; 82: 798-801.

9. Markowitz LE, Prelub SR, Fine PEM, Orenstein WA. Duration of live measles vaccine-induced immunity. Pediatr Infect Dis J 1990; 9: 101-110.

10. Murry, C. J. L. (). The global Burden of Disease 2000 project: aims methods and data sources, Global program on evidence for health policy. Bull WHO 2001: 36.

11. Davidkin, I., \& Valle, M. Vaccine-induced measles virus antibodies after two doses of combined measles, mumps and rubella vaccine: a 12-year follow- up in two cohorts. Vaccine 199816: 2052-7.

12. Van den HS, Berbers GA, de Melker HE, Spaendonck CMA. Sero-epidemiology of measles antibodies in the Netherlands, a cross-sectional study in a national sample and in communities with low vaccine coverage. Vaccine 1999;18(9-10): 931-40.

13. Whittle, H. C., Aaby P, Samb, B., Jensen, H., Bennett, J., $\&$ Simondon, F. Effect of subclinical infection on maintaining immunity against measles in vaccinated children in West Africa. Lancet1999; 353(9147): 98-102.

14. Janaszek W, Slusarczyk J. Immunity against measles in populations of women and infants in Poland. Vaccine 2003; 21(21-22): 2948-53.

15. Mossong J, O'Callaghan CJ, Ratnam S. Modelling antibody response to measles vaccine and subsequent waning of immunity in a low exposure population. Vaccine 2000; 19(4-5): 523-9.

16. Lee MS, Chien LJ, Yueh YY, Lu CF. Measles seroepidemiology and decay rate of vaccine-induced measles IgG titers in Taiwan, 1995-1997. Vaccine 2001; 19(32): 4644-51.

17. Markowitz LE, Albrecht P, Orenstein WA. Persistence of measles antibody after revaccination. J Infect Dis 1992; 166: 205-208.

18. Christenson B, Bottiger, M. Measles antibody: comparison of long term vaccination titers and naturally acquired immunity to and booster effects on the measles virus. Vaccine 1994; 12:129-133.

19. Cohn M, Robinson E, Faerber M, Thomas D, Geyer S, Peter S, et al. Measles vaccine failure: Lack of sustained measles-specific immunoglobulin $G$ responses in revaccinated adolescents and young adults. Pediatr Infect Dis J 1994; 13: 34-38. 
20. Johnson CE, Kumar ML, Whitwell JK. Antibody persistence after primary measles-mumps-rubella vaccine and response to a second dose given at four to six vs eleven to thirteen years. Pediatr Infect Dis J 1996; 15: 687-692.

21. Dai, B., Zhihui, C., Qichang L.(). Duration of immunity following immunization with live measles vaccine: 15 years of observation in Zhejiang Province, China. Bull WHO1991 ; 69: 415-423.

22. Muller, C. P., Huiss, S., Schneider, F. Secondary immune responses in parents of children with recent measles. Lancet $1996 ; 16 ; 348(9038)$ : 1379-80.

23. Islam AKMJ. Studies on measles antibody response among the vaccinated and unvaccinated children (Thesis) (2004). Bangabandhu Sheikh Mujib Medical Univ: Dhaka.

24. Janaszek, W., Gut, W., \& Gay, N. J. The epidemiology of measles in Poland: prevalence of measles virus antibodies in the population. Epidemiol Infect 2000; 125(2): 385-92.

25. Glass K, Grenfell BT. Waning immunity and subclinical measles infection in England. Vaccine 2004; 22: 4110-4116.
26. Gdalevich M, Robin G, Mimouni D, Grotto I, Shpilberg $\mathrm{O}$, Ashkenazi I. Measles antibody prevalence rates among young adults in Israel. Am J Infect Control 2002; 30(3): 165-9.

27. Tayil SE, Shazly EI, Amrawy MK, Ghouneim SM, AboudKhatwa FM, Masoud GM. Sero-epidemiological study of measles after 15 years of compulsory vaccination. Egypt Eastern Mediterranean health Journal 1998; 4:437-447.

28. Zahra, Y., Porali, R., Taravati, M. R., Salary, S., Khailily, F., Shahabi, S. Measles IgG Sero-Prevalence and its Attributable Factors in 5- 25 Year Old Cases Prior to Mass Vaccination Campaign in Urmia- Iran. Infectious Diseases Journal of Pakistan 2006; 62-66.

29. Lyamua EF, Matee MI, Aaby P, Scheutz F. Serum levels of measles IgG antibody activity in children under 5 years in Dar-es-Salam, Tanzania. Ann Trop Paediatr 1999; 19(2): 175-83. 